\title{
Improving Agricultural Science Teachers’ Work Attitude in Akwa Ibom State of Nigeria: The Financial Initiative Perspective
}

\author{
Camilus Bassey Ben ${ }^{1, *}$ \\ ${ }^{1}$ Agricultural Education Unit, Department of Vocational and Special Education, University of Calabar, Calabar, \\ Nigeria \\ *Correspondence: Agricultural Education Unit, Department of Vocational and Special Education, University of \\ Calabar, Calabar, Nigeria. Tel: 234-80-3426-6227. E-mail: camilusbassey@gmail.com
}

Received: April 30, 2014

Accepted: May 19, $2014 \quad$ Online Published: June 25, 2014

doi:10.5430/wje.v4n4p12

URL: http://dx.doi.org/10.5430/wje.v4n4p12

\begin{abstract}
This research study carried out to investigate the influence of financial incentive initiatives on agricultural teachers' work attitude in Akwa Ibom State, Nigeria. One hypothesis was formulated to guide the study. Ex-post facto research design was adopted for the study. A total sample of 150 agricultural science teachers and 150 students drawn from public secondary schools in the state were involved in the study. The financial Incentive Initiative Opinion Inventory (FIIOI) and Agricultural Teachers' Work Disposition (ATWD) questionnaires developed by the researcher were the instruments used for data collection. The data collected were statistically analyzed using the mean and independent t-test at 0.05 level of significance. The finding of the study indicated others, which financial incentive initiatives associated with adequate salary, and prompt payment, significantly influenced agricultural science teachers' work attitude. Based on these finding, it was recommended among others that the government should provide financial incentives to agricultural science teachers by paying their salaries adequately and promptly. This will motivate them towards improved work attitude.
\end{abstract}

Keywords: agricultural science teachers; work attitude; reward systems; financial initiative; incentive initiative

\section{Introduction}

The attainment of this goal depends to a large extent on ways and manners through which teachers vested with the responsibilities grooming the students are rewarded. Teachers' attitude to work may be positive or negative depending on the way they perceive the rewards attached to their jobs. In other words, the reward systems available to the teaching profession go a long way to determine how teachers perform their job. Incentive system in any organization is a means of sustaining the worker on the job. It is a motivating factor that influences the attitude of the worker on the job. According to ILO (2008) rewarding employees when appropriate shows them that, they are valued and that, their hard work and achievements are noticed. Rewards in the form of improved pay and fringe benefits affect the success or failure of an organization. Reward provides the incentive to achieve the top productivity from employees. Reward can drive desired behaviours, and improve job satisfaction. Some rewards may cost money, whereas others are investments in time and efforts. All can contribute to more pleasant work environment. Employees are motivated by work place atmosphere. Salaries and wages as incentive system that constitute a significant part of the overall cost of operations, observing that in some organizations salaries and wages constitute over $50 \%$ of the operating cost. As direct financial incentives, salaries and wages are the most emphasized among the teachers because it takes a centre stage as far as reward for work is concerned. In Akwa Ibom State, Nigeria, Agricultural Science teachers' take home pay is not commensurable to the work they do, given the tedious nature of their job. Besides, they are always looked down upon, they are not given their due recognition and respect. The society seems to rates them as a group of wretched individuals with no good houses to live in and people who cannot feed and dress well.

Financial rewards motivate employees to see the organization's mission as their own, instead of working for his own benefit. Ogunbameru (2004) concluded in his study that, a worker who is adequately rewarded remains with the organization. He pointed out it cost an organization quite a bit to deal with the loss of old employees and the training 
of new ones. Rewards given to those who are considering leaving may increase the organization's retention statistics and decreases long-term training costs. He recommended that government should encourage teachers to work harder and better from time to time by rewarding them adequately, since it goes a long way towards building self-motivation and improving job performance.

It is also surprising to note that teachers do not enjoy regular salaries payment. A teacher can also remain in one salary grade level for many years before being uplifted. When eventually uplifted, the financial benefits accrued to that might never be mentioned. This has in recent times resulted in open confrontation between the employer (government) and teachers. For teachers to perform their duty effectively, the average annual income for teachers as well as adequate provision for advancement, and benefits must be ensured. It is generally observed that the morale of teachers often low due to disparity in their salaries and those in other professions hence the mass exodus of teachers to more lucrative employment. The attitude of the teachers towards their job is a reflection of te financial benefit that the job offers them. A critical issue to consider both in developing an effective reward system and improving teachers' attitude to work is that of motivation. As pointed out by Ehondor and Omoruyi (2013), there are apathy and low morale in teaching job which ultimately resulted to poor work role disposition. This is so because although they have ability and prerequisite training, the financial reward system as at present is not sustainable to engender positive work disposition.

Every organization wants motivated employees that are more efficient and can produce better work outcome. Using monetary rewards to encourage positive attitude to work is a simple idea but implementing it judiciously and effectively can be challenging. A teacher's attitude to work may be positive or negative depending on the way they perceive the financial reward attached to their jobs. A policy that offers incentives in exchange for achievement can motivate all employees to prove their worth. When worker's productivity is high, the bottom line often increases far in excess of monetary reward distributed. Positive attitude to work can be encouraged through rewards, especially when they are tailored to felt needs of employees. For instance, if a teacher, who regularly writes notes of lesson, prepares assessment records, marks class register correctly, teaches with good students' performance in examinations is adequately rewarded financially, he will continue to maintain that good performance for more expected rewards. It was against this backdrop that this study was conceived.

\subsection{Statement of the Problem}

Akwa Ibom State is rated among the educationally advantaged state by the Federal Government of Nigeria. This is due to her precarious educational status among other pertinent indicators including consistent good academic performance of students over the years. While addressing the Principals of secondary schools on the performance of the Akwa Ibom State candidates in 2012 Senior Secondary School Examination (SSCE) conducted by West African Examinations Council, the commissioner for Education appreciated State performed brilliant performance of the candidates in the examination. The pass rate in Agricultural Science, he revealed was about 90\% and 85\% in 2011 and 2012 respectively. He attributed these good performances to positive attitude of some agricultural science teachers to working the school system. He pointed out that the government as the major administrator, manager, and stakeholder in education has invested enormous human and financial resources in providing educational input including building of new schools with agricultural input, instructional materials and other facilitates in the State. This is with intention to impact positively on teachers' and students' performance output. Inspite these laudable efforts, teachers' (including, Agricultural Science) efficiency and effectiveness in work disposition do not commensurate with the enormous expenditures in this sector and the constant agitation for salary increase, incentives and better working conditions always made by teachers. It should be noted that even when a stakeholder establishes new school farms, equips libraries with adequate Agricultural Science textbooks and provides well-equipped laboratories, if the teachers are not motivated through adequate financial reward structure which encompasses salaries and wages such efforts may not yield required positive results.

Adequate financial reward system for teachers of agriculture in schools is an imperative for optimized work role delivery. The Akwa Ibom State Government seems to have put in place financial initiatives for Agricultural Science teachers bordering on salaries and wages, promotion, professional development and working environment. However, the implementation of this has been either ignored or haphazardly done by the administrators saddled with the responsibility in this regard. It seems that the existing financial reward structure, vis-a- vis salaries, fringe benefits, and allowances as well as and working conditions do not satisfy agricultural teachers' basic needs. This probably accounts for their untoward disposition towards their job performance. 


\subsection{Purpose of the Study}

The main purpose for this study was to assess the financial inventive incentives and agricultural teachers' work attitude in Akwa Ibom State, Nigeria. Specifically, the study intended to find out the extent to which Agricultural Science teachers' work attitude is influenced by employers' financial incentive initiatives

\subsection{Research Question}

To guide the study, this research questions was posed; to what extent is Agricultural Science teachers' work attitude influenced by the financial incentive initiatives provided by the employers

\subsection{Statement of Hypotheses}

Agricultural Science teachers who receive adequate financial incentive initiatives do not significantly differ in their work attitude.

\section{Literature Review}

\subsection{The Employers' Financial Incentive Initiatives and Agricultural Science Teachers’ Work Attitude}

Financial incentive structure initiatives are compensation provided to employees in return for their services. Remunerations are usually in the form of wages. Wages are money paid to hourly-rated workers or casual workers. But a salary is a recompense or money paid to a person at regular intervals for performed services. Salaries are therefore fixed compensations paid to workers on a regular basis, say yearly, quarterly, monthly or even weekly depending on the organization. According to Shadid (2014) wages and salary administration refers to the development, implementation and on-going maintenance of a base pay system.

The central objective or purpose of wage and salary is to provide pay that is both competitive and equitable (Shadid (2014). Hard work and a high level of achievement can be rewarded financially. Educational institutions or organizations that seek to attract and retain highly productive and efficient employees cannot shy away from facing the challenges posed by the need to pay wages and salaries adequately in a competitive environment. The essence of wage and salary is to relate productivity to reward. Thus, teachers who manifest outstanding performance should receive extra pay to encourage them to do more. Ogunbameru (2004) emphasized the need to place premium on wages and salaries as a condition for increased performance. The high cost of living makes workers (teachers) to pressure their employers to increase pay. Teachers want their effort to be appreciated in terms of the amount of pay received by them. Thus, if pay is high, positive job attitude is likely to result. The ability of these financial benefits to motivate teachers towards higher commitment depends on their regularity.

Shadid (2014) in a related study concluded that, wages and salaries constitute a significant part of the overall cost in any organization, that establishment that lack the ability to pay wages and salaries regularly as in the case of the teaching profession are in danger of disintegration. He emphasized that poor wages and salaries are a constant source of frustration and can result to decline in productivity. Therefore, the ability of government to satisfy teachers' needs goes a long way to determine to some extent the attitude they would have towards their job. This, by implication means that teachers' attitude to job is a function of the extent to which they are satisfied with their wages and salaries. Financial incentives no doubt have the ability to motivate teachers towards their positive job disposition. However, a major challenge of financial incentives is that there is a usually limited fund available to handle them.

Ortyoyande and Agbe (2005) conducted a study to identify factors (in the ascending of the magnitude) that motivate Agricultural Science teachers into maximum job productivity. The findings indicated that salary was very paramount in teachers' performance. The finding further maintained that the teachers are paid low salary and this is compounded by late payment. This finding was not surprising at all. With late payment of salary, teachers can hardly plan with their earnings. A teacher who is well paid and on time is likely to put in his best to produce highly rated students. Salary is capable of motivating teachers to greater productivity and this could be manifested in students' performance.

Ferdiman (2007) concluded in a related from his study that student learning behaviour can be aroused, sustained, directed, and selectively reinforced by a highly committed teacher. He stressed that efficient learning by students and performance are predicted upon competent teachers' motivation. Leslie (2014) thus observed that teachers' salary is seen as a hypothesized cause of teacher productivity, the determinant of teachers' behaviours, arousal, vigour, direction and persistence. Adequate salary provides the "push" for teachers' competence. 
Ben (2014) carried out a study on quality assurance for effective Agricultural Teacher Preparation and school administration in Nigeria. The result of the analysis showed a significant relationship between teachers' incentive (in respect of salary), quality assurance and students' performance. Findings of the study indicated greater quality teachers' competence in teaching when enhanced salaries are paid and promptly. This competence could be manifested in improved students' academic performance.

Gabrielle and Hogan (2013) study on teachers' condition of service and teachers' competence concluded that if better pay-package and fringe benefits given to teachers are satisfactory by the teachers, they will put in more effort at work. They will prepare adequately for their lessons, go to school regularly and punctually, attend classes on schedule, teach the students well, administer, mark and record assignments, test and examinations. Most importantly, they will not take up secondary occupations' that has so much distracted their attention from their primary work role of recent. Teachers, like any other worker get employed in order to earn a living through salaries, become independent and cater for their family members. Thus, teachers' emolument affects their self-perception and status in the society. Their emolument also affects his other needs and values in life.

Gawel, (2013) in his analysis of Maslow's hierarchy of needs identified the physiological needs as the most basic needs of the individual. These are needs for food, clothing and shelter. Such basic needs according to the author are necessary to the proper functioning of the body. Other higher levels of needs will only become important after the physiological needs have been adequately satisfied. The satisfaction of the physiological needs in respect of the teachers is tied to financial remuneration. In the opinion of Dewguthridge, Mohr (2010) every person is motivated to obtain recognition and self-esteem and his take home pay is an important determinant of how need will be satisfied.

John (2006:57) conducted a related research on the applicability of Maslow's need theory among teachers in Akwa Ibom State and came up with the following findings:

Teachers valued the satisfaction of Physiological needs for competence and efficiency in job performance.

The level of needs satisfaction was significantly related to the extent of teachers' motivation, the degree of job satisfaction and subsequently, the teacher's competence.

(iii) Teachers' most important need was physiological while the least was social, and self-actualization generally was significantly related to their interest in the job.

He concluded that because teachers' physiological needs were not met, this adversely affected their job disposition. This could be understood since not much can motivate a teacher whose take home pay can neither 'take him home' nor reasonably satisfy his basic physiological needs. He remarked further that for a teacher who is extremely and dangerously hungry, no other interest exist but food. He dreams of food, perceive only food, and want only food. Hence, if at the end of the month, teachers cannot be sure of salary to sustain themselves and their dependents, they would be passive, nonchalant, and irresponsible to their school work. Idio (2008) observed that the main financial strategy for rewarding teachers are salaries and wages, bonuses, profit sharing plans, pension plans which should include redundancy, and retirement benefits and employees' stock ownership plans.

The Nigerian Union of Teachers (NUT) (2014) pointed out that working conditions of teachers is the learning conditions of the students and therefore made a case for teachers to be considered for Special Salary Scale distinct from public and other civil servants. Chiang and Birtch (2010) in their study on teaching conditions and implication for performance discovered that salaries and fringe benefit are important elements of interest to teachers. He stressed that the teachers' salaries and benefits dictate the tempo of the teaching job. A teacher who receives regular salaries and fringe benefits attached are more likely to be more committed to the job of teaching; their students too are likely to record better grades compared to teachers whose salaries are irregular and without fringe benefits. Ubon (2006) reported that any incentive scheme to be effective, it must meet the following basic fundamentals; the scheme should be fair to both employer and employees, to ensure complete trust on both sides. Secondly, the work content must be accurately measured and the worker should be paid in direct proportion to the individual effort rather than as a group. Thirdly, the scheme should be simple in operation, flexible, intimately connected to other management controls and should contain as much promotion for the slow, as for the fast workers among others.

Gawel (2013) pointed out that by implication; teachers are the technological mechanisms of any nation. However, Olukoya (2013) pointed out that teachers in Nigeria are not well treated in their job and that they seem the most wretched of the earth, the third class citizen in the third world country. He noted that if they are well catered for, the educational system will be bright and the students will receive sound education. If not well treated, even the good teachers will quit the teaching profession at the preponderance of mediocrity. This will impact negatively on academic performance of our students both in internal and external examinations. Making reference to Maslow 
hierarchy of need, Gawel (2013) remarks that human beings have certain needs that spur them into action. That gratification of such needs lead to satisfaction while frustration of such needs lead to dissatisfaction. He described need gratification as "the most important single principle underlying all development; and the single holistic principle that binds together the multiplicity of human motivates'.

Idio (2008) conducted a study on the impact of substantial investment in education, teacher training, and the implications on school transformation and economic development in Akwa Ibom state, Nigeria. The result showed a significant relationship between the two variables of need patterns and need satisfactions of teachers revealing that teachers regard the basic need, needs of security, social esteem, autonomy and self-actualization as very important to them, but these needs are rarely sufficiently met. Olaitan, Oyerinde, Obiyemi and Kayode (2010) studied professional differences in sources levels and symptoms of stress among teachers, lawyers and doctors in Nigeria. The investigations revealed that teachers' poor conditions of service in Nigeria are pathetically most source of stress because besides the very poor motivation which includes irregular payment of salaries, the school ethos is very poor and also demoralizing. The Nigerian Union of Teachers (NUT) (2014) supported Olaitan, et al (2010) in the revelation that in Nigeria, teachers' salaries are paid irregularly, promotions in most states have been suspended, staff development programmes such as in-service training, conferences etc. and other fringe benefits like car loans have been clamped down by the government. To her, these are dehumanizing situation that have adverse effects on teachers' motivation and consequently productivity. In a related vein, Diamond (2012) conducted a study which identified factors which contributed to the retention of primary school teachers. He used 60 trained primary schools teachers who had abandoned teaching for other lucrative ventures as subjects. The study identified economic disadvantages and lack of prospects for promotion as negative factors militating against teachers' motivation and effective performance.

Olukoya (2013) pointed out that the basic fringe benefits of teachers at whatever category is entitled to are not in dispute but that the teachers' motivation depend to a large extent on the authority (management) under which the teachers find themselves. The problem is that while some teachers receive the salaries with fringe benefits regularly, some may be paid salaries alone without fringe benefits, while some others are owed both salary and fringe benefits for months, depending on the authority concerned.

Holmes (2012) in her study on teachers' competence as a function of condition of service discovered that teacher's professional achievement as academic specialists depend on how they are treated by the government. She observed that motivated teachers have propensity for higher productivity. She suggested that teachers should be made to operate under better conditions of service so as to engender their optimal potentials. She also pointed out that teachers' competence is correlated to conditions of service. Teachers record poor performance when they are dissatisfied with their work conditions. In a study assessing factors responsible for students' poor performance in Geography, Marison and Mcnitre (2004) found teachers' condition of employment very important for teachers' competence as manifested in the students' performance. Nigeria Union of Teachers (NUT) (2014) stressed that when the management exhibits lackadaisical disposition for teachers' working condition or even refuse to pay salaries, teachers could decide to embark on industrial action or absenteeism or even exhibit lax attitudes towards teaching. This attitude impinges upon teachers' competence. When the competence is affected, students' performance is also affected.

\section{Methodology}

The ex-post facto research design was used for the study. The study was carried out in Akwa Ibom State, Nigeria. The population of the study was 1020 comprising agricultural Science teachers and students of senior secondary school classes. A simple random sampling technique was used to select a sample of 150 Agricultural Science teachers and 1150 senior secondary school students used for the study. The financial Incentive initiatives Opinion Inventory (FIIOI) meant for teacher respondents and Teachers Attitude Questionnaire (TAQ) meant for students to assess their teacher/ respondents attitude to work were used for data collection. The items focused on financial incentive initiatives which focused on adequacy and regularity of payment of salaries, wages and other allowances. The teachers Attitude Questionnaire ((TAQ) items measured motivation, punctuality, feedback and evaluation, commitment to work and attitude to teaching. To ascertain the reliability of the instrument, the instrument was pretested on 30teachers and 30 students through a test-retest method. The test-retest administrations yielded a reliability coefficient of 0.76 indicating that the instrument was reliable. 


\section{Presentation of Results}

\subsection{Hypothesis}

Agricultural Science teachers who receive financial incentive initiatives do not significantly differ in their work attitude.

Teachers in the sample were categorized into two groups based on their responses on the variable of financial incentive. Those who scored below the reference mean (of 15.00) were grouped under "lower level of financial incentives received", while those who scored at the reference mean and above were grouped under "high level of financial incentives received". The statistical analysis technique deployed to test this hypothesis was independent t-test. The results of the analysis are presented in Table 1.

Table 1. Independent t-test Analysis of Financial Incentive Initiative and Agricultural Science Teachers' Work Attitude

\begin{tabular}{|c|c|c|c|c|c|}
\hline Attitude sub-variables & $\begin{array}{c}\text { Level of } \\
\text { Financial } \\
\text { incentives }\end{array}$ & $\mathrm{N}$ & Mean & SD & t-value \\
\hline \multirow[t]{2}{*}{ i) Class motivation } & Low level & 112 & 26.861 & 1.86 & $3.463 *$ \\
\hline & High level & 88 & 25.882 & 2.02 & \\
\hline \multirow[t]{2}{*}{ ii) Punctuality } & Low level & 112 & 16.983 & 1.53 & $4.071^{*}$ \\
\hline & High level & 88 & 16.022 & 1.76 & \\
\hline \multirow[t]{2}{*}{ iii) Feedback/Motivation } & Low level & 112 & 14.031 & 1.76 & $3.693^{*}$ \\
\hline & High level & 88 & 13.243 & 1.47 & \\
\hline \multirow[t]{2}{*}{ iv) Commitment to work } & Low level & 112 & 15.112 & 1.38 & $4.277^{*}$ \\
\hline & High level & 88 & 14.146 & 1.73 & \\
\hline \multirow[t]{2}{*}{ v) Attitude to teaching } & Low level & 112 & 16.228 & 2.30 & $3.706^{*}$ \\
\hline & High level & 88 & 15.005 & 2.33 & \\
\hline
\end{tabular}

*significant at .05 level; critical $t=1.96, d f=198$.

The results in Table 1 show the mean, standard deviation and independent t-test analysis of financial incentive initiative and teachers' attitude to work. The comparison of the mean values of teachers with low level of financial incentives with the mean values of teachers with high level of financial incentives yielded t-values (absolute) of 3.463, 4.071, 3.693, 4.227 and 3.706 for classroom motivation, punctuality, feedback and evaluation, commitment to work and attitude to work respectively. Each of these calculated t-values (absolute) was higher than the critical t-value of 1.96 at .05 level of significance with 198 degree of freedom. With these results, the null hypothesis was rejected, implying that teachers' level of financial incentives received significantly influence their attitude to work in all the five dimensions. In other words, teachers who received financial incentives at the low level significantly differed from those who received it at the high level in their attitude to work in the five dimensions of classroom motivation, punctuality, feedback and evaluation, commitment to work and attitude to teaching.

\subsection{Discussion of Findings}

This discussion was done based on the specific objective of the study.

\subsection{Financial Incentives Initiative and Agricultural Science Teachers’ Attitude to Work}

The result of the study indicated that agricultural Science teachers who received financial incentives adopted positive job disposition than those teachers who did not. The finding was in line with the view of Ogunbameru (2004) who emphasized the need to place premium on wages and salaries as a condition for increased performance. Agricultural Science teachers want their effort to be appreciated in terms of the amount of pay received by them. Thus, if the pay is high, positive job attitude is likely to result. The ability of financial benefits to motivate teachers towards higher job commitment depends on regularity. Littlehood (2012) observed that, wages and salaries constitute a significant part of the overall cost in any organization, that establishment that lack the ability to pay wages and salaries regularly as in the case of the teaching profession are in danger of disintegration. Poor wages and salaries are a constant source of frustration and can result in declines in productivity. Therefore, the ability of government to satisfy teachers' needs goes a long way to influence the extent of the attitude they would have for their job. 
Ortyoyande and Agbe (2005) pointed out that salary was very paramount in teachers' performance. This was not surprising at all. Teaching profession in Nigeria is still a low status occupation, yet the services of teachers are indispensable. Teachers are confronted with the problem of low salary compounded by late payment to the extent that teachers can hardly plan for their earnings. An agricultural teacher who is well paid and on time is likely to put in his best to produce highly rated scholars since salary directly or indirectly influence the quality and quantity of services provided. Therefore salary is capable of motivating agricultural teachers to greater productivity as could be manifested in students' performance. Ferdiman's (2007) study also confirmed this finding that students' learning disposition can be aroused, sustained, directed, and selectively reinforced by a highly committed well motivated teacher. He stressed that efficient learning by students and performance are predicted upon competent teacher motivation. He views salary as a hypothesized cause of teachers' productivity, the determinant of teachers' arousal, vigor, direction and persistence besides serving as a "push" for teachers' competence.

\section{Conclusion}

Based on the pertinent findings, it was concluded therefore that financial incentive, one of the employers' reward systems initiatives for agricultural science teachers exert unalloyed effects on agricultural teachers' work disposition in Akwa Ibom State, Nigeria. The high quality of educational system in Akwa Ibom State depends on the quality of workforce). Moreover, the achievements of the students in the class are greatly influenced by the knowledge, skills, characters and commitment of the teachers. Teachers are in the frontline and contingent on what happens in the classroom in order to achieve the ultimate goal of delivery good-quality education. Improving students' performance needs to have teachers who are well trained, motivated. Adequate financial incentives in the form of salaries and working conditions plays a prime role for attracting, retaining, developing and retaining high-skilled and motivated teachers who are very important ingredient in the provision of quality education. Where Agricultural Science teachers are poorly paid, this condition will de-motivate them in effective teaching role. These points to the need for Agricultural science teachers to be paid adequate salaries and promptly to ginger them into optimized teaching work role performance.

\section{Recommendations}

Based on this finding, the following recommendations were made:

1. The salaries of Agricultural science teachers should to be paid adequate salaries and promptly.

2. Agricultural science teachers should be promoted regularly and the accompanied financial benefits paid promptly.

\section{References}

Akinbode, F. (2001). The effective social studies teacher. In F.A. Kinyale and C.O Kupolati (Eds)., The concept and scope of social studies education for schools and colleges. Ibadan: NERC.

Ben, C. B. (2014). Quality Assurance for Effective Agricultural Teacher Preparation and School Administration in Nigeria. Proceedings of INTCESS14-International Conference on Education and Social Sciences Proceedings. 3-5 February 2014- Istanbul, Turkey, 1706 -1712.

Chiang, F.F.T., \& Birtch, T.A. (2010). Reward climate and its impact on service quality orientation and employee attitudes. International Journal of Hospitality Management, 30(1), 26-37.

Dewhurst, M., Guthridge, M., \& Mohr, E. (2010). Motivating people: getting beyond Money. Retrieved May 3th, 2014 from www.samedayessay.com

Diamond, I. (2012). Improving Teaching and learning in Schools. Retrieved May 3th, 2014 from http/www.tlrp.org/pub/document/TLRP.x

Ehondor, S. E., \& Omoruyi, F.E.O. (2013). An assessment of the problems associated with the teaching/learning of computer science education in a Nigerian institution. Education Research Journal, 3(8), 192-196.

Ferdiman, J. (2007). Personality and personal growth in service. New York: Harper \& Row publishers.

Gabrielle, G., \& Hogan, J. (2013). The utilization, deployment, and management of teachers in Malawi, Botswana, South Africa and Uganda. Retrieved May 27, 2014 from information@iiep.unesco.org 
Gawel, J. E. (2013). Herzberg's theory of motivation and hygiene factors. Retrieved May 27th, 2014 from http://www.ericdigests.org/1999-1/needs.html

Holmes, E. (2012). Performance management changes: implication for teachers. Retrieved May $30^{\text {th }}, 2014$ from http://www.optimus-education.com/performance-management-changes-implications-teachers-and-cpd

Idio, I. (2008). The impact of substantial investment in education, workforce training, and the implications on school transformation and economic development in Akwa Ibom state. Educational Leadership, 65(8), 32-39.

International Labour Organization (ILO) (2008). Global Wage Report Geneva, P. 35.

John, M. E. (2006). Applicability of Maslow's need theory among teachers in Akwa Ibom State: Implications for educational administration. Unpublished M.Ed Thesis, University of Calabar, Calabar, Nigeria.

Leslie, T. (2014). Linking efficiency to compensation. Retrieved May 27 ${ }^{\text {th }}$, 2014 from http://www.salary.com/productivity-bonuses/

Littlehood, B. (2012). Acase study of Public school teachers. Retrieved May 27 ${ }^{\text {th }} 2014$ from www.likeessay.com/essays/education

Marison, A., \& McIntyre, D. (2004). Teachers and teaching. London: John Whiley.

Nigeria Union of Teachers (NUT) (2014). Welfare for teachers still begging for attention. Retrieved May $30^{\text {th }}$, 2014 from www.teacher.org

Ogunbameru, O. A. (2004). Organizational dynamics. Abuja: Spectrum Books Ltd.

Olaitan, O., Oyerinde, O. O., Obiyemi, O., \& Kayode, O. O. (2010). Prevalence of job stress among primary school teachers in South West Nigeria. African Journal of Microbiology, 4(5), 339-342.

Oluyola, A. (2013). NUT advocates enhanced teachers' welfare. Retrieved May 28 ${ }^{\text {th }}, 2014$ from www.teacher.org

Ortyoyande, R., \& Agbe, S. (2005). Motivation and teachers'quality in schools. Research in Art Education, 4(3), 14-23.

Shadid, K. V. (2014). Wages and salary administration. Retrieved from http://www.scribd.com/doc/17295150/Wages-and-Salary-Administration 